\title{
Special Issue on Testis Cancer
}

\author{
Daniel Nettersheim ${ }^{1} \cdot$ Peter Albers $^{2}$
}

Published online: 28 February 2022

(c) The Author(s) 2022

Germ cell tumors of the testis are rare cancers with-for unknown reasons-rising incidence in industrialized countries affecting young men in their reproductive ages peaking at 20-30 and 30-40 years depending on histology. These special circumstances demand different diagnostic and monitoring tools, different counseling and different multidisciplinary treatment goals as compared to classical oncology at elderly ages.

First, nearly all patients can be cured, some of them by orchidectomy alone, some by a combination of cisplatinbased therapy and surgery. This demands precautions in the treatment recommendations focusing on long-term rather than short-term toxicity in this young patients' population and alternatives to the cisplatin-based therapy are warranted. Second, if spreading at all, germ cell tumors remain largely in the lymphatic drainage system and hematogenous spread is late, comparatively rare, and dependent on presence of special histologic components, like choriocarcinoma or yolksac tumor. This asks for very thoughtful and precise diagnosis and staging before recommending treatment. Third, a small entity of germ cell tumors harbors treatment-resistant cell clones, which need to be identified as early as possible and characterized on a molecular level to identify the underlying mechanisms of therapy-resistance. Even patients with such resistant disease patterns can be cured. Lastly, all this implies that physicians treating patients with germ cell tumors need to be counseled, second opinion before treatment should be standard and advanced metastatic patients need to be treated in highly specialized centers.

Peter Albers

Peter.Albers@med.uni-duesseldorf.de

Daniel Nettersheim

Daniel.Nettersheim@med.uni-duesseldorf.de

1 Department of Urology, Urological Research Laboratory, Translational UroOncology, Medical Faculty and University Hospital Düsseldorf, Heinrich Heine University Düsseldorf, Düsseldorf, Germany

2 Department of Urology, Düsseldorf University Hospital, Medical Faculty, Düsseldorf, Germany
In this special issue, many of the above-mentioned prerequisites to treat patients suffering from germ cell tumors with cutting-edge knowledge and technology are presented by international experts in the field. The modern diagnostic work-up as presented by Zengerling [1], Belge [2], and Brandt [3] et al. will soon include not only magnetic resonance imaging to avoid diagnostic toxicity in young ages, but will also include new tumor markers, like microRNA371a$3 \mathrm{p}$, for better non-invasive staging. The consequence of this more precise staging possibilities may be the broader indication for local and less traumatic treatment options like robotic RPLND and resection of small seminoma metastases as presented by Hamilton [4] and Daneshmand et al.[5]. Additional preoperative imaging calculations ("radiomics") may aid in surgical planning as outlined by Nini et al.[6]. Furthermore, the fruitful collaboration of dedicated medical oncologists and specialized surgeons may improve the outcome of patients with resistant disease as presented by Oing [7], and Hiester et al. [8]. Lastly, Bremmer and Nettersheim et al. [9] identified putative factors of cisplatin resistance on proteome level by mass spectrometry. Taken together, this special issue presents up-to-date knowledge and future perspectives on the management and research of patients with germ cell tumors. These developments will influence oncology. As such, testis cancer remains a role model of oncology.

Funding Open Access funding enabled and organized by Projekt DEAL.

Open Access This article is licensed under a Creative Commons Attribution 4.0 International License, which permits use, sharing, adaptation, distribution and reproduction in any medium or format, as long as you give appropriate credit to the original author(s) and the source, provide a link to the Creative Commons licence, and indicate if changes were made. The images or other third party material in this article are included in the article's Creative Commons licence, unless indicated otherwise in a credit line to the material. If material is not included in the article's Creative Commons licence and your intended use is not permitted by statutory regulation or exceeds the permitted use, you will need to obtain permission directly from the copyright holder. To view a copy of this licence, visit http://creativecommons.org/licenses/by/4.0/. 


\section{References}

1. Wakileh GA, Ruf C, Heidenreich A et al (2021) Contemporary options and future perspectives: three examples highlighting the challenges in testicular cancer imaging. World J Urol. https://doi. org/10.1007/s00345-021-03856-6

2. Dieckmann KP, Dumlupinar C, Radtke A et al (2021) Associations of serum levels of microRNA-371a-3p (M371) with risk factors for progression in nonseminomatous testicular germ cell tumours clinical stage 1. World J Urol. https://doi.org/10.1007/ s00345-021-03876-2

3. Brandt MP, Ruf C, Dieckmann KP et al (2021) Clinical characteristics, treatment patterns and relapse in patients with clinical stage IS testicular cancer. World J Urol. https://doi.org/10.1007/ s00345-021-03889-x

4. Nason GJ, Hamilton RJ (2022) Robotic RPLND for stage IIA/B nonseminoma: the princess margaret experience. World J Urol. https://doi.org/10.1007/s00345-021-03899-9

5. Alsyouf M, Daneshmand S (2021) Clinical stage II seminoma: management options. World J Urol. https://doi.org/10.1007/ s00345-021-03854-8
6. Nini A, Boschheidgen M, Hiester A et al (2021) Preoperative clinical and radiographic predictors of major vascular surgery in patients with testicular cancer undergoing post-chemotherapy residual tumor resection (PC-RPLND). World J Urol. https://doi. org/10.1007/s00345-021-03870-8

7. Seidel C, Hentrich M, Zschäbitz S et al (2022) Peritoneal carcinosis in male germ cell tumor patients: a registry study compiled by the German Testicular Cancer Study Group (GTCSG). World J Urol. https://doi.org/10.1007/s00345-021-03905-0

8. Che Y, Lusch A, Winter C et al (2021) Late relapsing germ cell tumors with elevated tumor markers. World J Urol. https://doi.org/ 10.1007/s00345-021-03833-z

9. Fichtner A, Bohnenberger H, Elakad O et al (2022) Proteomic profiling of cisplatin-resistant and cisplatin-sensitive germ cell tumour cell lines using quantitative mass spectrometry. World $\mathbf{J}$ Urol. https://doi.org/10.1007/s00345-022-03936-1

Publisher's Note Springer Nature remains neutral with regard to jurisdictional claims in published maps and institutional affiliations. 